\title{
TTR
}

Traduction, terminologie, rédaction

\section{Luise von Flotow and Reingard M. Nischik, eds. Translating Canada. Charting the Institutions and Influences of Cultural Transfer: Canadian Writing in German/y. Ottawa, University of Ottawa Press, "Perspectives on Translation," 2007, 344 p.}

\section{Denise Merkle}

Volume 22, numéro 2, 2e semestre 2009

Littérature comparée et traductologie littéraire : convergences et divergences

Comparative Literature and Literary Translation Studies: Points of Convergence and Divergence

URI : https://id.erudit.org/iderudit/044836ar

DOI : https://doi.org/10.7202/044836ar

Aller au sommaire du numéro

Éditeur(s)

Association canadienne de traductologie

ISSN

0835-8443 (imprimé)

1708-2188 (numérique)

Découvrir la revue

Citer ce compte rendu

Merkle, D. (2009). Compte rendu de [Luise von Flotow and Reingard M. Nischik, eds. Translating Canada. Charting the Institutions and Influences of Cultural Transfer: Canadian Writing in German/y. Ottawa, University of Ottawa Press, "Perspectives on Translation," 2007, 344 p.] TTR, 22(2), 264-267.

https://doi.org/10.7202/044836ar

Tous droits réservés @ TTR: traduction, terminologie, rédaction — Les auteurs, 2010
Ce document est protégé par la loi sur le droit d'auteur. L'utilisation des services d'Érudit (y compris la reproduction) est assujettie à sa politique d'utilisation que vous pouvez consulter en ligne.

https://apropos.erudit.org/fr/usagers/politique-dutilisation/ 
En privilégiant l'observation pour comprendre en profondeur le phénomène étudié et pour en dégager les relations et les lois, le tournant descriptiviste a non seulement généré de nombreux projets de recherche dans les contextes et les problématiques extrêmement diversifiés, mais a aussi alimenté les débats épistémologiques et méthodologiques au sein de la discipline.

Il reste désormais à changer de centration, c'est-àdire à réfléchir sur l'herméneutique du sujet traduisant, ce qui permettrait d'ouvrir la porte à la dimension critique et éthique de la traduction, ainsi qu'aux circuits de traduction qui se forment $\mathrm{au}$-delà des frontières étatiques et qui rendent de plus en plus problématique ce concept crucial chez Toury : la norme.

\section{Aurelia Klimkiewicz Université York, Collège Glendon}

Luise von Flotow and Reingard M. Nischik, eds. Translating Canada. Charting the Institutions and Influences of Cultural Transfer: Canadian Writing in German/y. Ottawa, University of Ottawa Press, "Perspectives on Translation," 2007, 344 p.

This welcome contribution to Canadian Translation Studies has brought together fourteen essays, all written in English, that reflect on Canadian literature in German translation. Canadian literature is not to be understood here as exclusively English-Canadian, which is an all too common international misconception. To some extent the tendency to separate more or less categorically (English-)Canadian literature from Quebec literature stems from the labours of two autonomous and strong associations: the International Council for Canadian Studies and the Association internationale des études québécoises. Rather this collection has moved beyond the binary opposition that divides English-Canadian and Québécois literatures, for it includes essays on Franco-Quebec literature, minority Franco-Canadian literatures and First Nations' literature, as well as the expected Anglo-Canadian literature. Furthermore, a broad spectrum of genres are covered, for chapters have been devoted to the study 
of women's writing, children's literature, theatre, the essay, in addition to the novel, in German translation.

Generally speaking, the chapter's title gives a good indication of its content: "Translated or Traduced? Canadian Literary and Political Theory in a German Context: Northrop Frye, Michael Ignatieff, and Charles Taylor" (Georgiana Banita); "The 'AlterNative' Frontier: Native Canadian Writing in German/y" (Eva Gruber); "From Beautiful Losers to No Logo! German Readings of Jewish Canadian Writing" (Fabienne Quennet); "French, Female, and Foreign: French Canadian [sic] Children's Literature in German Translation" (Nikola von Merveldt); "Selecting Canadiana for the Young: The German Translation of English Canadian Children's Literature" (Martina Seifert); "Contemporary (English) Canadian Plays in German/y. Equivalence in Difference?" (Albert-Reiner Glaap); "Northern Lights in German Theatres: How Quebec Plays Come to Germany" (Andreas Jandl, translated by Luise von Flotow); "Low Motility: Transferring Montreal Playwright Stephen Orlov's Sperm Count to Germany" (Brita Oeding); "Two Solitudes'? Anglo-Canadian Literature in Translation in the Two Germanies" (Barbara Korte); "Translating the Canadian Short Story into German" (Klaus Peter Müller); and "Margaret Atwood in German/y: A Case Study" (Stefan Ferguson). Klaus-Dieter Ertler, whose chapter ("Antonine Maillet in German: A Case Study," pp. 283-291) was also translated by Luise von Flotow, examines problems of linguistic transfer from Acadian French to German and the muted German reception of the translation of Antonine Maillet's Pélagie-la-Charette. In addition to writing the lead essay that expounds on the theoretical underpinnings of the collection, Von Flotow co-authored with Brita Oeding "The 'Other Women': Canadian Women Writers Blazing a Trail into Germany." The contributors are leading or "up-and-coming" German-speaking Canadianists, Translation Studies scholars and translation practitioners from North America and Europe who treat the subject of their respective chapters with academic rigour. A pioneer of Canadian Literature Studies in Europe, Reingard M. Nischik of the University of Constance co-edited the volume in collaboration with Von Flotow, and co-signed the introduction. 
This ambitious collection is the first Canadian, and perhaps international, collection to deal so comprehensively with cultural, specifically literary, transfer between nations, and was in preparation during a time (late 1990s and early 2000s) when the Department of Foreign Affairs and Trade was calling out to Canadians to act as "citizen-diplomats" on the world stage. It sets out to examine how, why and when Canadian literary products entered German-language literary systems (former German Democratic Republic (DDR) and Federal Republic of Germany (BRD), (unified) Germany, Austria, Switzerland) thanks to the work of translators and editors between 1967 and 2000, alongside the relationship between their reception and soft diplomacy. The detailed and generally well-documented chapters cover a broad range of literary products, although they deal predominantly with fiction (Korte, Müller, Oeding/Von Flotow, Ferguson, Gruber, Quennet, Seifert, von Merveldt, Ertler) and to a lesser extent with theatre (Glaap, Jandl, Oeding). They clearly show that translators, whether from within Canada's borders or the target culture's borders (translators in the former BRD, DDR and in Austria), have worked and continue to work as cultural diplomats-often in (close) collaboration with editors who facilitate the transfer of "brand Canada" into the German-speaking world.

Luise von Flotow argues convincingly in her lead essay, "Telling Canada's 'Story' in German: Using Cultural Diplomacy to Achieve Soft Power," that literary translation is a significant contributor to intercultural communication. She takes the position that it is unacceptable for Canadian decision-makers in areas of foreign affairs and international trade to continue to be silent with respect to the essential role that translation-and interpretation-has played and continues to play in the political and international trade arenas, often through the transfer of cultural products. Although not a major shortcoming, it is regrettable that the chapters (with the exception of Oeding's and Glaap's) do not deal more explicitly with the influence of translating literature on cultural, political and trade relations (soft power) between Canada and Germany or Austria, since Von Flotow's innovative thesis effectively arouses interest in this issue. Undoubtedly, the publication will encourage scholars (possibly those who work in disciplines other than Translation Studies or 
Literary Studies) to explore the link between literary translation and "soft power" not only in German-speaking countries, but in other countries as well. Clearly, this book not only provides a comprehensive overview of Canadian, German and Austrian cultural institutions (from funding and government agencies, to newspaper "feuilleton," publishers and universities) involved in the transfer of Canadian literary products, but it also awakens reader interest to learn more about them.

The high quality of the editorial work must be lauded given that the vast majority of the collaborators are writing in their second (or third) language. Moreover, the volume is well documented, thanks to a name and title index in addition to a subject index that help the reader locate information. A subsequent edition might consider adding an index of tables.

The publication could prove useful as a reference book to a broad spectrum of readers: Translation Studies and Canadian Studies researchers, government officials, students, publishers, translators, writers, etc., who wish to learn how Canadian cultural, in this case literary, products enter a foreign literary system, their impact on the system and the image(s) of Canada and Canadians that have marked the target system. A place should be reserved for the book on the shelves of any (university) library that has a section on Canadian Studies, Cultural Studies or Translation Studies. Given its readability, this book could be used as a textbook in undergraduate courses, not only graduate ones, and in a broad range of disciplines including international trade and foreign affairs.

\author{
Denise Merkle \\ Université De Moncton
}

